\title{
Bioleaching of Galena (PbS)
}

\author{
E. R. Mejía ${ }^{1}$, J. D. Ospina ${ }^{1}$, M. A. Márquez ${ }^{1}$ and A. L. Morales ${ }^{2}$ \\ ${ }^{1}$ Materials Engineering School, Applied Mineralogy and Bio-process Group (GMAB) \\ National University of Colombia, Medellín AA 1027, \\ ${ }^{2}$ Solid State Group, University Research Centre \\ Antioquia University, Medellín AA 1226, \\ Colombia
}

\section{Introduction}

Microbial leaching of metals from sulfide minerals has been widely studied (Marsden $\mathcal{E}$ House, 1992; Brierley e Luinstra, 1993; Partha \& Nataraja, 2006; Watling, 2006; Al-Harahssheh et al., 2006). However, few studies have reported on the bacterial oxidation of galena (PbS) to insoluble lead sulfate (Santhiya et al., 2000; Da Silva, 2004a and b). Formation of lead sulfate prevents the recovery of lead from traditional solvent extraction via electrowinning routes (Da Silva, 2004b).

Galena is a mineral of vast industrial importance, not only for being the world's main source of lead, but also for being a semiconducting material with a band gap around of $0.4 \mathrm{eV}$ (Muscat et al., 2003). Sulfide materials are also of interest from an environmental perspective as they are a major cause of water system acidification in mining operations.

In contrast to studies on galena, great attention has been paid to the bioleaching of sphalerite $((\mathrm{Zn}, \mathrm{Fe}) \mathrm{S})$ (Muscat \& Gale, 2003). This interest stems from the increasing need to process grade ores of mixed mineralogy (Da Silva, 2004b; Muscat \& Gale, 2003). One particular problem is the common association of sphalerite with galena, especially at fine particle sizes, which could complicate the differential flotation of the two minerals (Da Silva, 2004; Liao \& Deng, 2004; Bolorunduro et al., 2003). Although the kinetics and mechanism of sphalerite bioleaching are well known, they are not completely understood (Da Silva, 2004a,b; Boon et al., 1998; Paar et al., 1984; Rodrigez et al., 2003; Zapata et al., 2007).

Two different minerals can be selectively bioleached with galvanic interactions where the mineral with lower rest potential is sacrificed and that with higher potential is passivated (Das et al., 1999; Suzuki, 2001; Da Silva, 2004a,b; Abraitis et al., 2004; Cruz et al., 2005; Urbano et al., 2007).

The mechanism of galena oxidation is important in flotation processes, where mineral oxidation, through the grinding/flotation circuit, can affect its hydrophobicity and, therefore, its interaction with surfactants (Da Silva, 2004; Jañezuk et al., 1993; Nowak et al., 2000; Peng et al., 2002). However, the pretreatment of refractory ores to recover metals from lower-grade sulfide ores or refractory minerals is unusual in Colombia (Muñoz et al., 2003). 
This leads to economic losses in mining processes, especially in subsistence mining. Their implementations in mining and metallurgical industries are also very attractive (Flower et al., 1999; Rohwerder et al., 2003; Olson et al., 2003).

In this work, biological oxidation of galena was performed using Acidithiobacillus ferrooxidans-like bacteria and a mixed culture. Characterization techniques such as scanning electron microscopy (SEM), X-ray diffraction (XRD), and Fourier transform infrared spectroscopy (FTIR) were used to follow the morphologic and chemical changes occurring during the process.

\section{Materials and methods}

\subsection{Minerals}

All experiments were carried out using a galena sample from an El Silencio miner, property of Frontino Gold Mines Company (Segovia, Antioquia, Colombia). The mineral was subjected to crushing and milling processes followed by gravimetric separation in a Wilfley table. Manual concentration using stereographic microscopy was then performed. The mineralogical composition of the concentrate measured by countdown points was $93.3 \%$ galena (PbS), 6.2\% sphalerite (ZnS), and 0.5\% chalcopyrite $\left(\mathrm{CuFeS}_{2}\right)$ for -200 Tyler and $90 \%$ galena (PbS), $7.5 \%$ sphalerite $(\mathrm{ZnS}), 0.7 \%$ chalcopyrite $\left(\mathrm{CuFeS}_{2}\right)$, and $1.8 \%$ gangue $\left(\mathrm{SiO}_{2}\right)$, for -325 Tyler. An agate mortar was used to obtain two particle sizes: a pass through 200 Tyler mesh $(\sim 75 \mu \mathrm{m})$ and a pass through 325 Tyler mesh $(\sim 45 \mu \mathrm{m})$. XRD results confirmed that galena was the principal mineral phase in both sizes (Fig. 1). The mineral was sterilized in a furnace at $80^{\circ} \mathrm{C}$ for $90 \mathrm{~min}$.
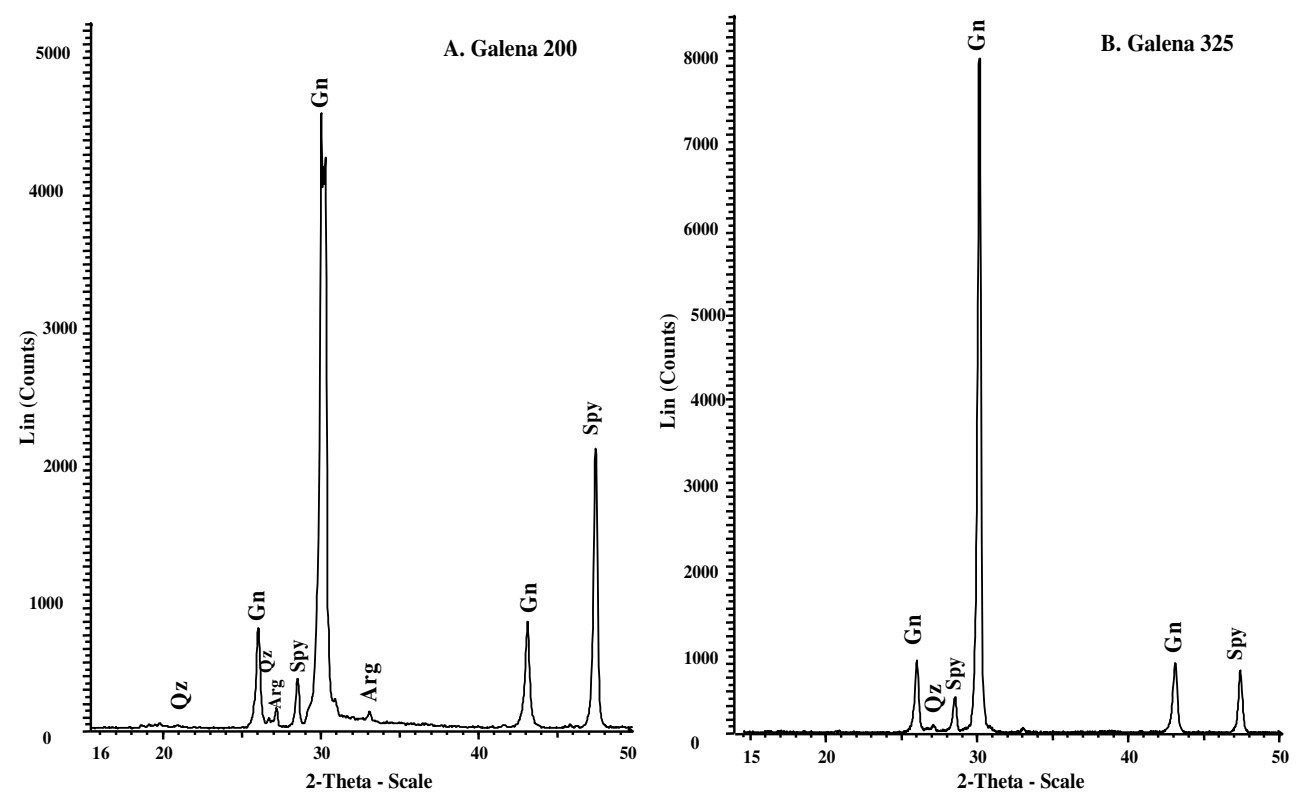

Fig. 1. X-ray spectra of the concentrates. Mineral pass through A) 200 and B) 325 Tyler mesh 


\subsection{Bioleaching experiments}

A. ferrooxidans- and Acidithiobacillus thiooxidans-like strains were used in the bioleaching experiments. The strains were isolated by Cardona (2008). The microorganisms were previously grown in T\&K medium by successive replacement of the ferrous sulfate with galena. The medium was acidified to $\mathrm{pH} 1.8$ using $\mathrm{H}_{2} \mathrm{SO}_{4}$. The flasks were sterilized by autoclaving for $20 \mathrm{~min}$ at $120^{\circ} \mathrm{C}$ and $18 \mathrm{psi}$. The experiments were inoculated with $A$. ferrooxidans $10 \%(\mathrm{v} / \mathrm{v})$ for the single culture and $A$. ferrooxidans $5 \%(\mathrm{v} / \mathrm{v})$ and $A$. thiooxidans $5 \%(\mathrm{v} / \mathrm{v})$ for the mixed culture. The experiments were carried out for 30 days in $500 \mathrm{~mL}$ shake flasks containing $300 \mathrm{~mL}$ of medium with $10 \%(\mathrm{w} / \mathrm{v})$ galena at $180 \mathrm{rpm}$ and $30^{\circ} \mathrm{C}$. All conditions were duplicated and the respective abiotic control was included.

\subsection{Chemical analysis}

Measurements of $\mathrm{pH}$ (HACH HQ40d multi PHC30103) and redox potential (Shot Handylab $1 \mathrm{Pt}$ 6880) in situ (reference electrode $\mathrm{Ag}^{0} / \mathrm{AgCl}$ ) were performed daily. Samples were aseptically withdrawn from the flasks after $24 \mathrm{~h}$ and then every five days. The samples were separated in a DIAMOND IEC DIVISION centrifuge for $15 \mathrm{~min}$ at $3000 \mathrm{rpm}$. Iron and sulfate concentrations were measured using an ultraviolet-visible spectrophotometer GENESYSTM 10. The methods employed included 3500-FeD (O-phenanthroline) for ferrous and total iron according to the standard methods for water analysis.

\subsection{Mineralogical analysis}

Combinations of analytical techniques were used in the mineralogical characterization of the samples. The FTIR spectra of the solid samples were recorded by an FTIR spectrophotometer (Shimadzu Advantage 8400) using $\mathrm{KBr}$ pellets in transmission mode. A sample $\mathrm{KBr}$ mixture at a ratio of 1:200 was used. The total number of scans was 20, and a spectral resolution of 4 $\mathrm{cm}^{-1}$, a range of 400-4000 $\mathrm{cm}^{-1}$, and Happ-Henzel correction were used.

The biooxidation samples were mounted in epoxy resin and polished with sequentially finer $\mathrm{SiC}$ grit paper followed by a final polish with $0.05-\mu \mathrm{m}$ sized alumina powder. Analysis of the polished sections was performed with a JEOL JSM 5910 LV SEM in backscattering electron mode with an energy dispersive X-ray (EDX) detector (Oxford Instruments), using a beam voltage of $18 \mathrm{kV}$. XRD analyses of the samples were conducted on a Bruker D8ADVANCE diffractometer with $\mathrm{Cu} \lambda=1.5406 \AA$ radiation generated at $35 \mathrm{kV}$ and $30 \mathrm{~mA}$. XRD data were obtained using computer-controlled X-ray Diffractometer Panalytical X'Pert Pro MPD. The initial characterizations of the mineral-polished sections were performed by optical microscopy of reflected light.

\section{Results}

\subsection{Galena leaching experiments using $A$. ferrooxidans}

Variation on $\mathrm{pH}$ and redox potential (Eh) values for the inoculated systems and the abiotic controls are presented in Fig. 2. In order to prevent inhibition of the bacteria, $\mathrm{H}_{2} \mathrm{SO}_{4}$ was added to maintain the $\mathrm{pH}$ values around 2.0 until day 15 . The $\mathrm{pH}$ values first increased and then decreased over time to levels around 1.1. The $\mathrm{pH}$ values in the abiotic controls stabilized at around 2.0 after day 15. 

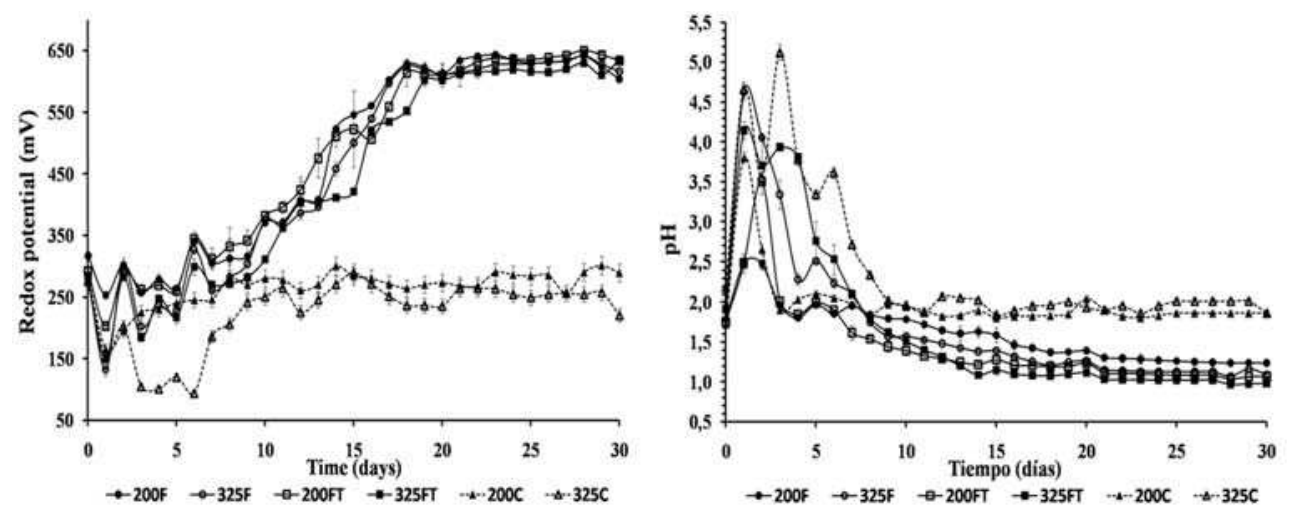

Fig. 2. Changes in redox potential and $\mathrm{pH}$ during the bacterial oxidation process. Graph legend: 200F, test with Acidithiobacillus ferrooxidans and 200 Tyler mesh; 325F, test with $A$. ferrooxidans and 325 Tyler mesh; 200FT, test with consortium and 200 Tyler mesh; 325FT, test with consortium and 325 Tyler mesh; 200C, inoculate test with 200 Tyler mesh; and 325C, inoculate test with 325 Tyler mesh

The variation in redox potential in both cultures with different grain sizes presented a relatively low redox potential at the beginning of the test until day 11 followed by an increase and finally a stationary phase with a small decrease with time. Eh values in the abiotic controls were around $284 \mathrm{mV}$ throughout the processes. The $\mathrm{SO}_{4}{ }^{2-}$ concentration in the solution as well as in the solid phase gradually increased with time. However, the increase of sulfate concentration was greater in the solid phase than in the solution (Fig. 3).
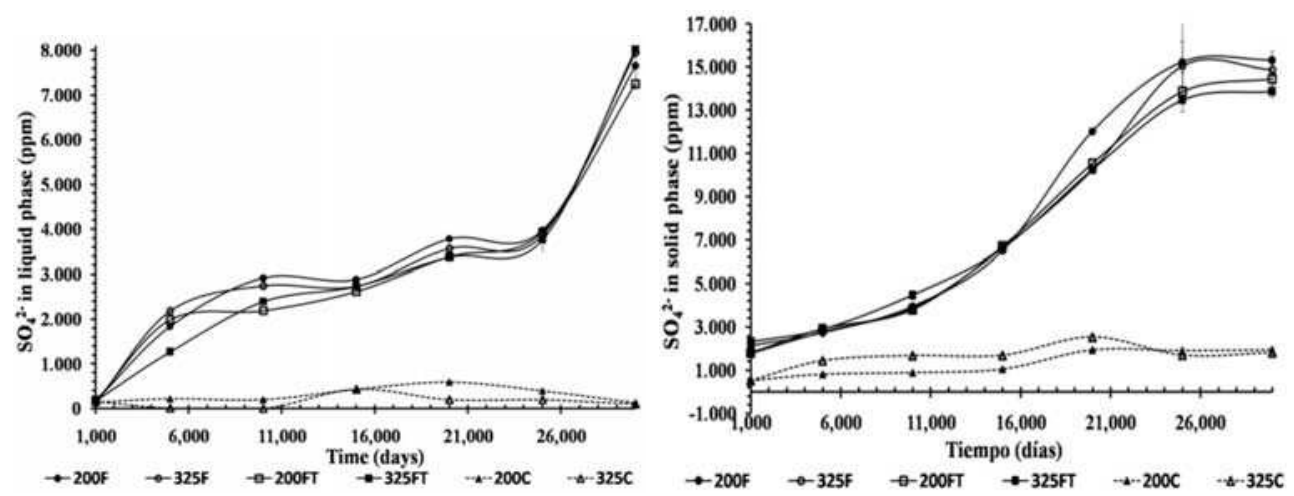

Fig. 3. Changes in $\mathrm{SO}_{4}^{2-}$ during the bacterial oxidation process. Graph legend: 200F, test with Acidithiobacillus ferrooxidans and 200 Tyler mesh; 325F, test with A. ferrooxidans and 325 Tyler mesh; 200FT, test with consortium and 200 Tyler mesh; 325FT, test with consortium and 325 Tyler mesh; 200C, inoculate test with 200 Tyler mesh; and 325C, inoculate test with 325 Tyler mesh

The dissolution of $\mathrm{Fe}^{2+}$ increased and reached a maximum during days 6-15. It then decreased sharply, becoming somewhat stationary with a small decrease on day 25 (Fig. 4). 

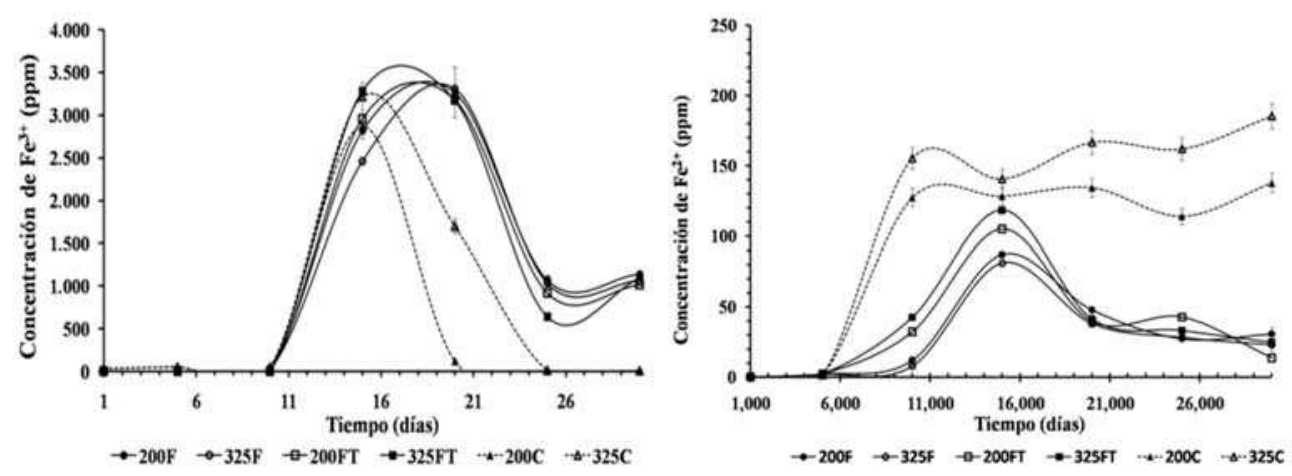

Fig. 4. Changes in $\mathrm{Fe}^{2-}$ and $\mathrm{Fe}^{3+}$ during the bacterial oxidation process. Graph legend: $200 \mathrm{~F}$, test with Acidithiobacillus ferrooxidans and 200 Tyler mesh; 325F, test with A. ferrooxidans and 325 Tyler mesh; 200FT, test with consortium and 200 Tyler mesh; 325FT, test with consortium and 325 Tyler mesh; 200C, inoculate test with 200 Tyler mesh; and 325C, inoculate test with 325 Tyler mesh

In the abiotic experiments, ferrous iron increased between day 5 and 10 and then remained stationary until the end of the process. The $\mathrm{Fe}^{3+}$ increased from day 10 to day 15, became stationary until day 25, and finally decreased sharply to about $1 \mathrm{ppm}$, where it remained until the end of the experiment. Lead extraction was around $57 \%$ for all texts. On the other hand, $<5 \%$ of $\mathrm{Pb}$ was solubilized in the chemical controls (Fig. 5).

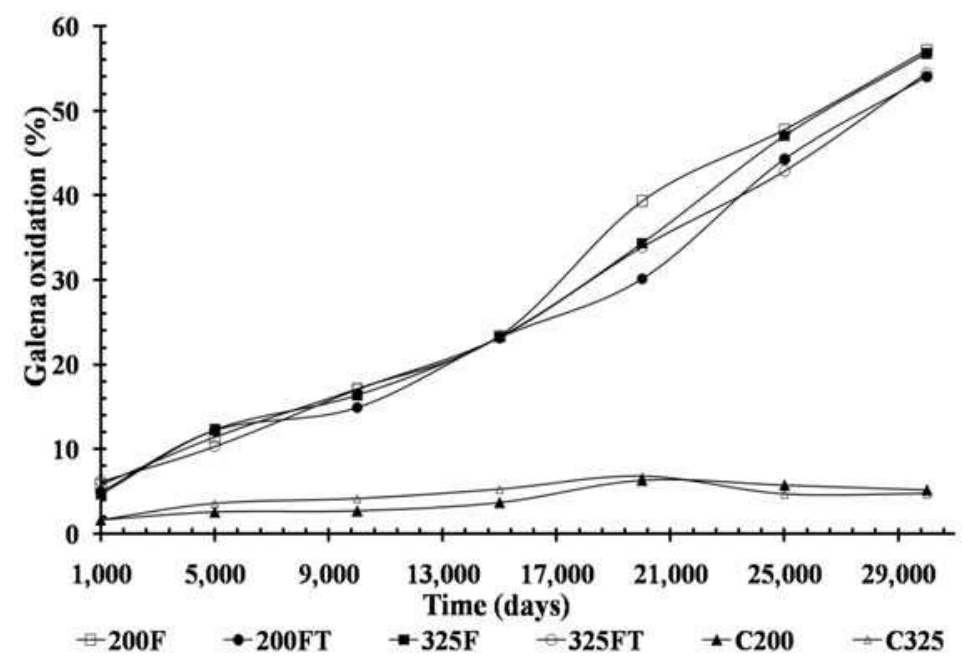

Fig. 5. Galena oxidation during the bacterial oxidation process. Graph legend: 200F, test with Acidithiobacillus ferrooxidans and 200 Tyler mesh; 325F, test with A. ferrooxidans and 325 Tyler mesh; 200FT, test with consortium and 200 Tyler mesh; 325FT, test with consortium and 325 Tyler mesh; 200C, inoculate test with 200 Tyler mesh; and 325C, inoculate test with 325 Tyler mesh 


\subsection{FTIR}

Results obtained by FTIR for the bioleached galena samples showed typical bands of anglesite, the main mineral product of the process, with absorption bands at 950-1000, 11651765, 1115-1125, 1050-1060, and 592-620 $\mathrm{cm}^{-1}$ (Chernyshova, 2003). Scotlandite $\left(\mathrm{PbSO}_{3}\right)$ was also identified by bands at 920, 870, 970, and 600-620 $\mathrm{cm}^{-1}$ (Paar et al., 1984; Chernyshova, 2003). The bands around $2935 \mathrm{~cm}^{-1}$ related to the total carbon present on the cell surface increased permanently (Naumann \& Helm, 1995; Sharma \& Hynumantha, 2005; Xia et al., 2008).The FTIR spectra showed at the beginning of the process, for all tests, an increased numbers of anglesite and scontlandite bands.

The tests conducted using A. ferrooxidans with different grain sizes presented a continuous increase in the bands of the anglesite and scontlandite until day 10, followed the strong band increases. This was possibly due to the strong anglesite and scontlandite precipitate. It then increased continuously until day 20. Finally, the typical bands of anglesite and scontlandite showed a strong increase (Figs. 6a and 6b). However, the FTIR spectra for the test conducted using the mixed culture with different grain sizes presented continuous increases in the anglesite and scontlandite bands throughout the process (Figs. 6c and 6d).
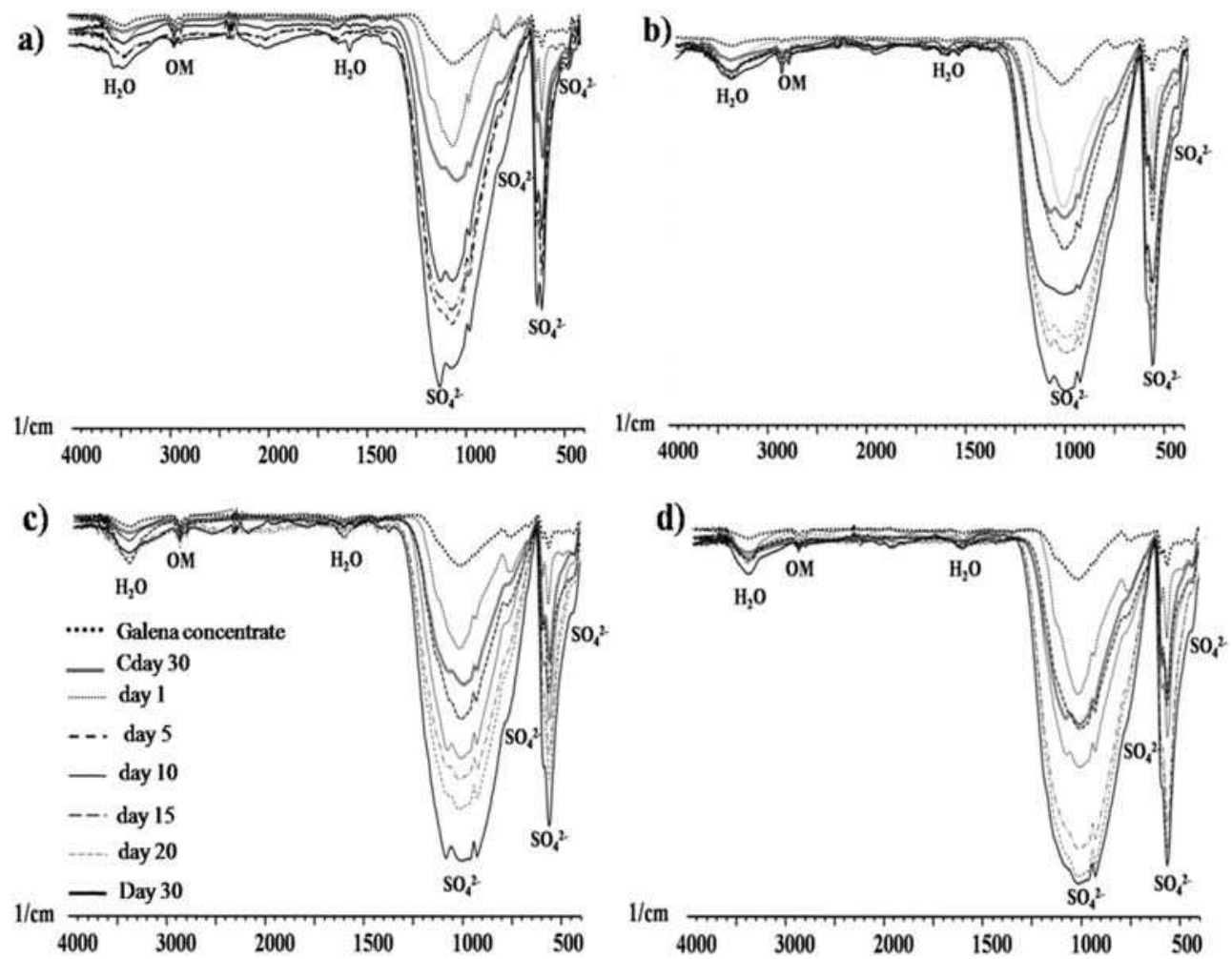

Fig. 6. Fourier transform infrared spectra of solid residues after galena bioleaching. OM, organic matter; $\mathrm{SO}_{4}^{2-:}$ anglesite 


\subsection{SEM/EDX}

SEM images of leached galena are shown in Figs. 7, 8, and 9. All of the samples had corrosion features such as pits and gulfs on the grain surfaces (Figs. 7H and 7I). Moreover, coarse particle size porous films coating grains (Figs. 7C, 7F, and 7L), and aciculate precipitates of anglesite (Figs. 7D and 7L) were observed. These characteristics became observable on day 7 of the process (Figs. 7A, 7B, 7G, and 7H) and were more evident with time. After day 15, the galena grains were coated with anglesite film with porous texture (Figs. 7C and 7K). The anglesite aciculate formations were more evident at the end of the process (Fig. 7L). It is important to note the passivating effect that galena has on sphalerite and pyrite in which the pyrite and sphalerite grains did not show evidence of oxidation (Figs. 7C, 7D, 7J, 7F, and 7L).
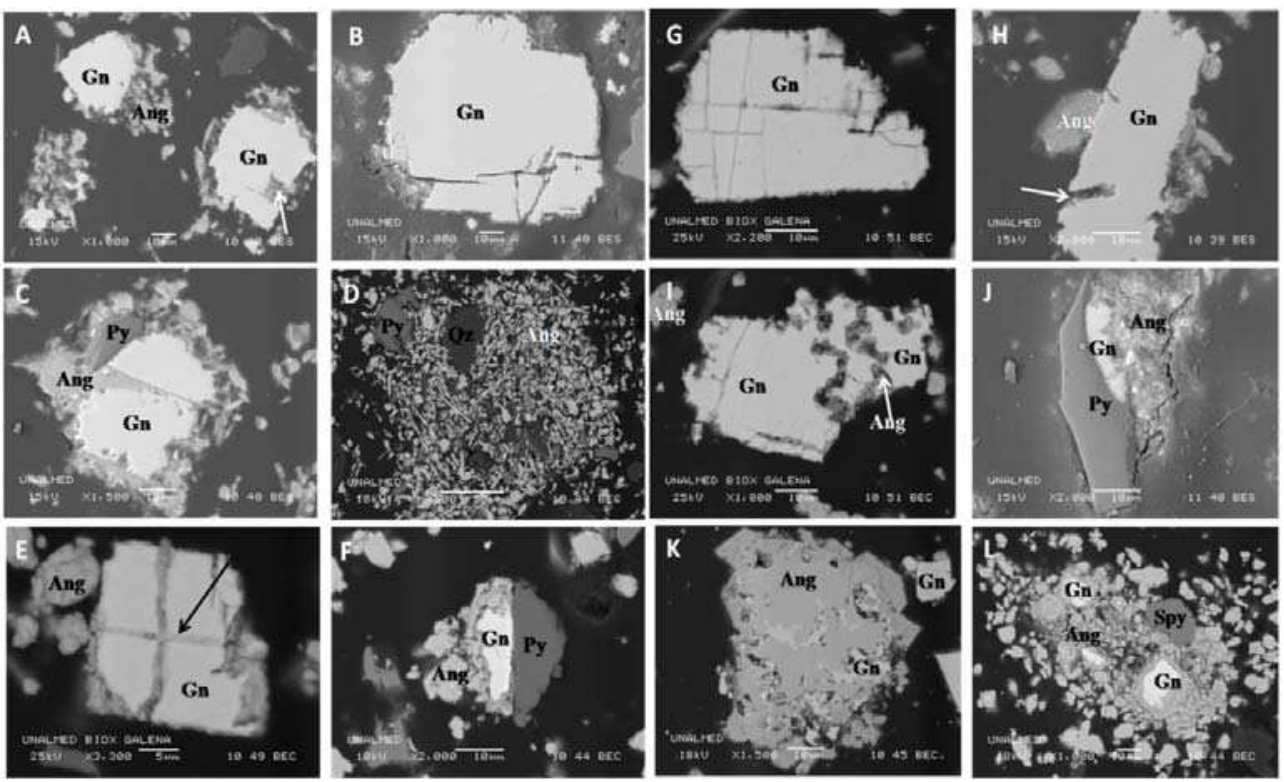

Fig. 7. Scanning electron microscopy micrograph of the residues after galena bioleaching by passing through 200 (A, B, C, D, E, and F) and 325 (G, H, I, J, K, and L) Tyler mesh. Gn, galena; Ang, anglesite; Py, pyrite. A) Galena grain and aciculate anglesite precipitates (arrows indicate corrosion gulfs on day 5). B) Galena grain in an incipient oxidation state (day 5). C) Galena grain covered and coated with anglesite porous film and pyrite grain without apparent oxidation (day 15). D) Anglesite grains aciculate and anhedrals, quartz grains without apparent oxidation and pyrite grains in the insipient oxidation state (day 15). E) Galena grain oxidant along the cleavage plane (arrows indicate cleavage plane) and anglesite grain (day 30). F) Galena grain covered and coated with anglesite porous film and pyrite grain without apparent oxidation (day 30). G) Galena grain corroded in gulfs and cleavage plane (day 5). H) Galena grain in an incipient oxidation state showed gulfs of corrosion (day 5). I) Galena grain corroded with anglesite cavity formation (day 15). J) Galena grain covered and coated with anglesite porous film and pyrite grain without apparent oxidation (day 15). K) The anglesite was porous and had a remaining galena nucleus. L) Anglesite grains aciculate and anhedrals and galena grains coated with anglesite porous film and sphalerite grain without apparent oxidation 
However, in some cases, we observed sphalerite and pyrite grains with oxidation grooves at the end of the process (Figs. $8 \mathrm{~A}$ and $8 \mathrm{~B}$ ). Moreover, we observed remaining galena and anglesite nuclei with porous texture (Figs. $7 \mathrm{~K}$ and $8 \mathrm{~B}$ ). On other hand, some galena grains showed oxidation along the cleavage planes (Figs. 7E and 7G). SEM images of the uninoculated samples for all tests (Figs. 8a and $8 b$ ) showed surfaces with a few alterations such as small oxidation in the cleavage planes.
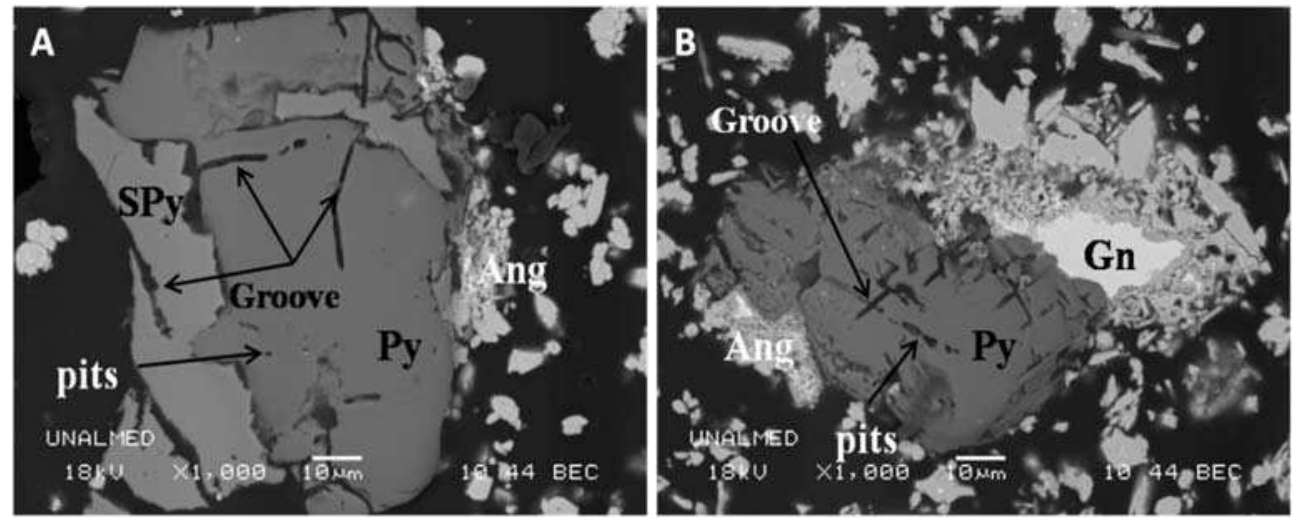

Fig. 8. Scanning electron microscopy micrograph of the residues after galena bioleaching. Gn, galena; Ang, anglesite; Py, pyrite; and Spy, sphalerite. A) Sphalerite and pyrite grains showed a typical corrosion groove and pits and porous anglesite. B) Pyrite grain with corrosion grooves, remaining galena nucleus, and porous anglesite
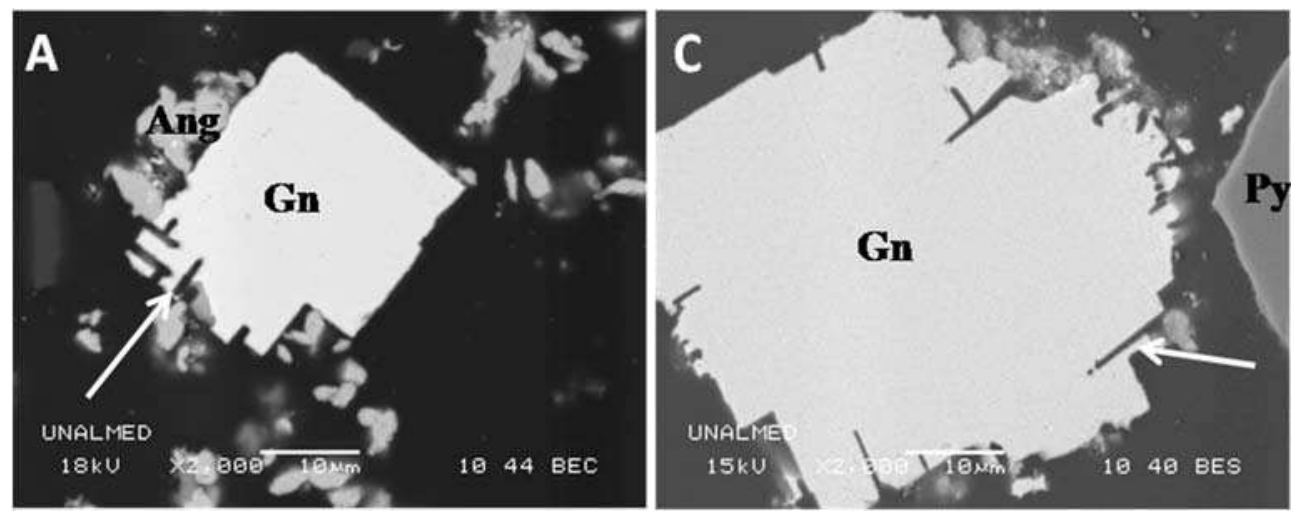

Fig. 9. Scanning electron microscopy micrographs of uninoculated residues after galena bioleaching. A) Galena grain with insipient oxidation state along the cleavage plane (pass through 200 Tyler mesh) and anglesite aciculate on the galena surface. B) Galena grain with an incipient oxidation state along the cleavage plane (pass through 325 Tyler mesh), and pyrite without an oxidation state. Cpy, chalcopyrite; Qz: quartz

EDX analysis of the grains showed the galena, anglesite, pyrite, and sphalerite stoichiometric composition (Table 1). 


\begin{tabular}{|l|r|r|}
\hline \multicolumn{3}{|c|}{ EDS Sphalerite } \\
\hline Element & Weight $\%$ & Atomic\% \\
\hline $\mathrm{S}$ & 28,20 & 44,88 \\
\hline $\mathrm{Fe}$ & 8,60 & 7,72 \\
\hline $\mathrm{Zn}$ & 60,79 & 46,59 \\
\hline $\mathrm{Cd}$ & 1,90 & 0,85 \\
\hline
\end{tabular}

\begin{tabular}{|l|r|r|}
\hline \multicolumn{3}{|c|}{ EDS Anglesite } \\
\hline Element & Weight $\%$ & Atomic $\%$ \\
\hline $\mathrm{O}$ & 17,83 & 61,66 \\
\hline $\mathrm{S}$ & 11,24 & 19,40 \\
\hline $\mathrm{Pb}$ & 70,93 & 18,94 \\
\hline
\end{tabular}

\begin{tabular}{|l|r|r|}
\hline \multicolumn{3}{|c|}{ EDS Pyrite } \\
\hline Element & Weight $\%$ & Atomic $\%$ \\
\hline $\mathrm{S}$ & 49,42 & 62,99 \\
\hline $\mathrm{Fe}$ & 50,48 & 37,01 \\
\hline
\end{tabular}

\begin{tabular}{|l|r|r|}
\hline \multicolumn{3}{|c|}{ EDS Galena } \\
\hline Element & Weight $\%$ & Atomic\% \\
\hline $\mathrm{S}$ & 12,97 & 49,06 \\
\hline $\mathrm{Pb}$ & 87,03 & 50,94 \\
\hline
\end{tabular}

Table 1. Energy dispersive spectrography (EDS) analysis of the residues after bioleaching of galena

\subsection{XRD analysis}

Initial XRD analyses revealed that galena was the main mineral phase present in the original samples, with small quantities of quartz $\left(\mathrm{SiO}_{2}\right)$, sphalerite $(\mathrm{ZnS})$, chalcopyrite $\left(\mathrm{CuFeS}_{2}\right)$, and aragonite (Fig. 1). XRD spectra of bioleached samples are shown in Fig. 11. Mineralogical evolution of the mineral phases consists of a gradual reduction of galena peaks and the appearance of anglesite $\left(\mathrm{PbSO}_{4}\right)$. Anglesite peaks were observed from day 5 onward for all samples. However, peak intensity was higher in concentrate passed through -325 Tyler mesh. The sphalerite peaks remained unchanged throughout the process. XRD for uninoculated controls showed minimal anglesite formation around day 30 (Fig. 10).

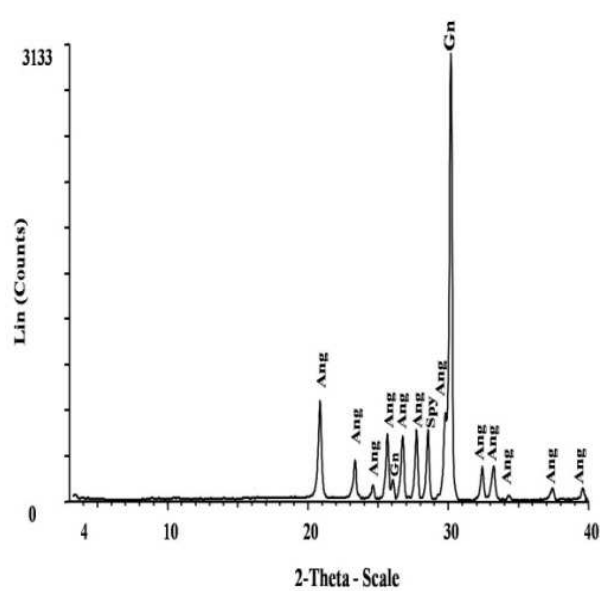

(A)

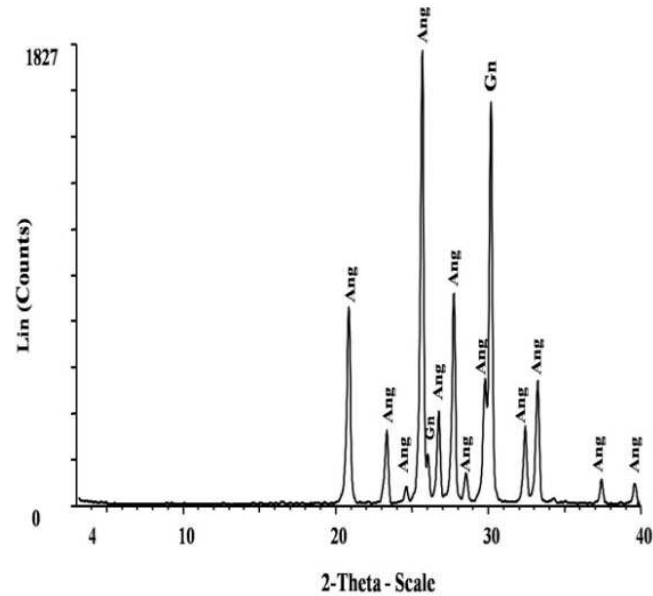

(B)

Fig. 10. X-ray diffractograms of inoculated samples after 30 days of the biooxidation process. A) Sample passed through -200 Tyler mesh; B) Sample passed through -325 Tyler mesh. Gn, galena; sph, sphalerite; and Ang, anglesite 

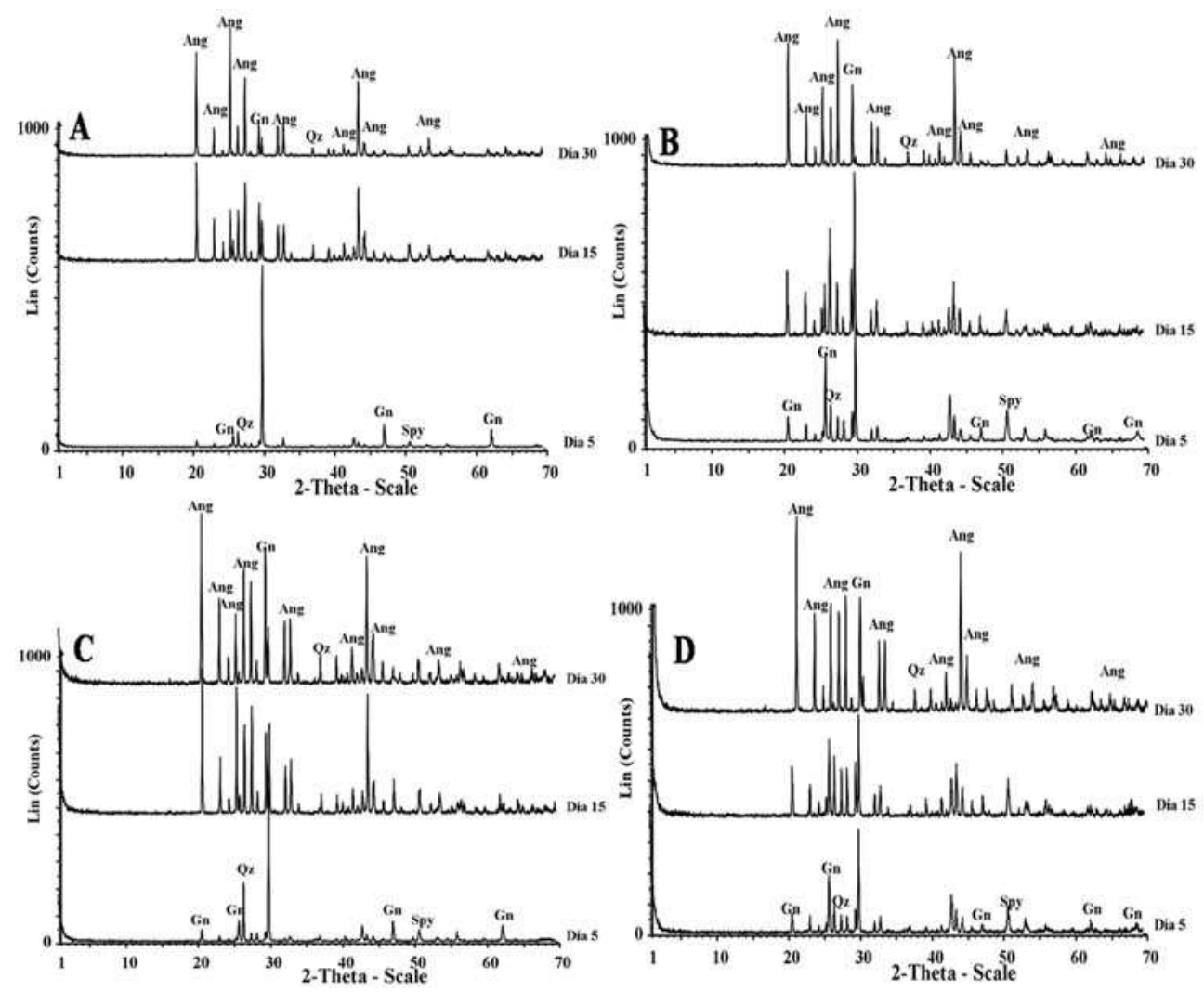

Fig. 11. X-ray diffraction spectra for galena before the bioleaching process. A. Particle size using 200 Tyler mesh for pure culture. B. Particle size using 325 Tyler mesh for the pure culture. C. Particle size using 200 Tyler mesh for the mixed culture. D. Particle size using 325 Tyler mesh for the mixed culture. Gn, galena; sph, sphalerite; Qz, quartz; and Ang, anglesite

\section{Discussion}

\subsection{Galena leaching experiment}

A. ferrooxidans-like bacteria showed good adaptation on galena with a high oxidative capacity (SEM, FTIR, XRD, and chemical data) since the microorganism was grown in a mineral concentrate that was the only source of energy. Jiang et al. (2008) stated that the bacteria may directly oxidize galena by taking energy from it. However, several authors suggest that $A$. ferrooxidans does not have a direct effect on galena oxidation; rather, it only indirectly acts on it via oxidizing hydrogen sulfide $\left(\mathrm{H}_{2} \mathrm{~S}\right.$ ) and sulfur (Da Silva 2004; Muscat \& Gale, 2003; Garcia et al., 1995). Thus, A. ferrooxidans utilizes $\mathrm{H}_{2} \mathrm{~S}$ dissolved in the solution as an energy source (Dutrizac \& Chen, 1995; Mizoguchi \& Habashi, 1981) according to the following equations:

$$
\mathrm{PbS}+\mathrm{H}_{2} \mathrm{SO}_{4} \rightarrow \mathrm{PbSO}_{4}+\mathrm{H}_{2} \mathrm{~S}
$$




$$
\begin{gathered}
2 \mathrm{H}_{2} \mathrm{~S}+\mathrm{O}_{2} \text { bacteria } \rightarrow 2 \mathrm{~S}+2 \mathrm{H}_{2} \mathrm{O} \\
2 \mathrm{~S}+2 \mathrm{H}_{2} \mathrm{O}+3 \mathrm{O}_{2} \text { bacteria } \rightarrow 2 \mathrm{SO}_{4}^{2-}+4 \mathrm{H}^{+}
\end{gathered}
$$

Furthermore, this study suggests that galena biooxidation also produces anglesite $\left(\mathrm{PbSO}_{4}\right)$ by reacting with sulfuric acid as shown in equation 1 .

This finding is in agreement with the results obtained in this work in which $\mathrm{Pb}^{2+}$ was released from galena and precipitated as lead sulfate. Nevertheless, in accordance with the results obtained by FTIR, where there was evidence of the presence of scontlandite $\left(\mathrm{PbSO}_{3}\right)$, it is possible that the anglesite was not the only sulfate mineral phase and was able to generate other $\mathrm{PbS}$ mineral phases as accessories.

On other hand, the solubility of $\mathrm{Pb}^{2+}$ is very low, around $45 \mathrm{ppm}$ (Mousavi et al., 2006), and the $\mathrm{SO}_{4}{ }^{2-}$ increased gradually in the solid and liquid phases (Fig. 3), being higher in solids (Fig. 4). This finding indicates that $\mathrm{Pb}^{2+}$ and $\mathrm{SO}_{4}{ }^{2-}$ or $\mathrm{SO}_{3}{ }^{2-}$ ions react to form anglesite $\left(\mathrm{PbSO}_{4}\right)$ and scontlandite $\left(\mathrm{PbSO}_{3}\right)$ as shown in equations 6 and 7. Moreover, anglesite $\left(\mathrm{PbSO}_{4}\right)$ was detected in the residual solid and increased over time according to FTIR, XRD, and SEM analysis. This phenomenon can be represented by the following equations:

$$
\begin{aligned}
\mathrm{PbS}+\mathrm{H}_{2} \mathrm{SO}_{4}+0.5 \mathrm{O}_{2} & \rightarrow \mathrm{PbSO}_{4}+\mathrm{H}_{2} \mathrm{O}+\mathrm{S}^{0} \\
2 \mathrm{PbS}+\mathrm{H}_{2} \mathrm{SO}_{4}+3 / 2 \mathrm{O}_{2} & \rightarrow 2 \mathrm{PbSO}_{3}+\mathrm{H}_{2} \mathrm{O}+\mathrm{S}^{0} \\
\mathrm{~Pb}^{2+}+\mathrm{SO}_{4}^{2-} & \rightarrow \mathrm{PbSO}_{4} \\
\mathrm{~Pb}^{2+}+\mathrm{SO}_{3}^{2-} & \rightarrow \mathrm{PbSO}_{3}
\end{aligned}
$$

However, elemental sulfur was not detected by SEM, XRD, or FTIR. Moreover, the pH (Fig. 2) decreased after six days around to 1.3 for all tests after it was 1.8, indicating that the increased $\mathrm{H}^{+}$concentration was produced by bacterial activity. This behavior was due to the galena dissolution in an acid environment occurring as a result of the protonation of the mineral surface. The only protonation mechanism that has been proven to be energetically favorable in aqueous solution consists of the attachment of three $\mathrm{H}^{+}$onto three surface $\mathrm{S}$ atoms surrounding a central $\mathrm{Pb}$ atom, which is then replaced by a fourth $\mathrm{H}^{+}$(equation 1).

$$
\mathrm{PbS}+\mathrm{H}_{2} \mathrm{SO}_{4} \rightarrow \mathrm{PbSO}_{4}+\mathrm{H}_{2} \mathrm{~S}
$$

This work detected few changes in chemical controls in galena oxidation and $\mathrm{SO}_{4}{ }^{2-}$ in solid and liquid concentration at the beginning of the process, indicating that galena dissolution was favored in acid media via a purely chemical mechanism. This finding is in agreement with those of Gerson \& O'Deo (2003) and Acero et al. (2007).

The bacteria oxidize $\mathrm{H}_{2} \mathrm{~S}$, generating elemental sulfur and water (equation 1). Elemental sulfur is also oxidized by bacteria producing sulfates and $\mathrm{H}^{+}$(equation 2 ).

$$
2 \mathrm{H}_{2} \mathrm{~S}+\mathrm{O}_{2} \text { bacteria } \rightarrow 2 \mathrm{~S}+2 \mathrm{H}_{2} \mathrm{O}
$$

The $\mathrm{H}^{+}$reattach to the mineral and, thus, generate a cycle. This resulted in great dissolution in the inoculate tests (around 57\%) compared with the uninoculated test. 
On the other hand, on day 10, when the concentration of $\mathrm{Fe}^{3+}$ was high probably due to biooxidation of the minor quantities of sphalerite and pyrite (Fig. 4), galena oxidation was favored, possibly indicating that this ion contributes to the overall process efficiency. Jiang et al. (2007) found that ferric can oxidize galena and generate elemental sulfur according to the following reaction:

$$
\mathrm{PbS}+2 \mathrm{Fe}^{3+} \rightarrow \mathrm{Pb}^{2+}+2 \mathrm{Fe}^{2+}+\mathrm{S}^{0}
$$

It is important to emphasize that the behaviors of the kinetic parameters analysis were similar for both culture types. This finding was probably due to the fact that the $\mathrm{pH}$ value was highly unstable at the beginning of the process, increasing to around 4.0, inhibiting $A$. thiooxidans. This suggested that this type of microorganism was unable to obtain energy from galena and required elemental sulfur addition as an additional energy source. On the other hand, the particle size used did not generate test differences.

\subsection{Mineralogical analysis}

Mineralogical studies indicated that anglesite was the predominant mineral phase of galena biooxidation. The presence of anglesite was not clear, and evidence of passivation of the galena biooxidation process was seen in the galena oxidation curve, which was linear and increased throughout the process (Fig. 5), and the SEM images, where anglesite grains with remaining galena nuclei were observed on day 30 (Figs. 7K and 8B). The formation of this mineral phase was confirmed by the FTIR spectra, which showed increased numbers of anglesite and scontlandite bands at the beginning of the process for all tests, probably because anglesite and scontlandite present precipitate pulse (Fig. 6). This sharp increase was observed on days 10 and 20 for the tests using A. ferrooxidans, and its further slow increases on the other days of the process were consistent with sharp increases in the chemical sulfate data (Fig. 3). The FTIR spectra for the test conducted using the mixed culture presented continuously increased numbers of bands of anglesite and scontlandite throughout the process (Figs. 6C and 6D).

On the other hand, the band increases at 2935 and $2847 \mathrm{~cm}^{-1}$ organic matter was possibly due to an increase in bacterial population, indicating bacterial activity (Naumann et al., 1995; Sharma et al., 2005; Xia et al., 2008). Furthermore, SEM analysis indicated that galena dissolution in the presence of the microorganisms occurred on the surface due to the presence of grain roughening, dissolution gulf formation (Figs. 7A and 7H), and preferential cleavage planes dissolution (Fig. 7E), all of which increase with time. The anglesite precipitation phenomenon occurs because the solubility limit of lead and sulfates in the medium is exceeded and could be mitigated by a sulfate concentration reduction in the medium. Moreover, SEM analysis revealed anglesite film precipitation on the galena grain from day 15 onward (Fig. 7C).

The preferential oxidation of the galena cleavage planes was probably due to the fact that this region was more potentially favorable or more chemically reactive because this zone has higher surface energy and, therefore, was easily oxidized as demonstrated by Bennett and Tributsch (1978).

XRD analysis (Fig. 10) indicated that anglesite $\left(\mathrm{PbSO}_{4}\right)$ was formed at the expense of galena dissolution. In contrast, the galena in the control reaction system showed a few alterations. Nevertheless, dissolution of the minority phases as sphalerite can be observed. 
Finally, mineralogical data showed the passivating effect of galena on pyrite and sphalerite (Figs. 7F and 7L, respectively), in which the latter, with a higher rest potential, is provided at the expense of galena oxidation, which acts as the sacrificial anode in agreement with earlier studies (Das et al., 1999; Suzuki, 2001; Da Silva 2004b; Abraitis et al., 2004; Cruz et al., 2005; Urbano et al., 2007). However, in some cases, dissolution was observed in pyrite and sphalerite grains (Figs. 8A and $8 \mathrm{~B}$ ). These data confirmed that $\mathrm{Fe}^{2+}$ lixiviation likely originates from the minor quantities of sphalerite and pyrite that are present in the sample concentrate. However, the rest potential of sphalerite is less than that of pyrite, which possibly indicates that iron leached into sphalerite, but high iron concentration in solution (Fig. 4) apparently indicates that the pyrite made an important contribution. Moreover, the iron content of sphalerite (around $8.6 \%$ weight) was smaller than that of pyrite (around $50.48 \%$ weight) (Table 1 ).

\section{Conclusions}

Examinations of the bioleaching of natural galena concentrate in T\&K medium by $A$. ferrooxidans-like bacteria and mixed culture resulted in the following conclusions:

- The bacteria have an impact on higher yield in the course of reaction of oxidizing PbS into $\mathrm{PbSO}_{4}$ in acid medium (1.8), and experiments were inoculated with Acidithiobacillus ferrooxidans $10(\mathrm{v} / \mathrm{v}) \%$ and $5 \%(\mathrm{v} / \mathrm{v})$ for the single culture and Acidithiobacillus thiooxidans $5 \%(\mathrm{v} / \mathrm{v})$ with $10 \%(\mathrm{w} / \mathrm{v})$ galena. Where there was released the lead from galena and precipitated as lead sulfate. The level of lixiviation after 30 days of bioleaching was $57 \%$, whereas that of the control examination was only $6 \%$.

- $T h e \mathrm{Fe}^{3+}$ favored the biolixiviation of galena because when its concentration increased, galena dissolution was favored.

- The predominant new mineral phase was anglesite, a porous film that was formed on galena, but this film did not limit the access of the leaching agent and microorganisms inside the grain.

- In the presence of bacteria, the XRD peaks corresponding to galena decreased and, at the same time, new peaks appeared, anglesite, during the bioleaching process. This signal became more intense over time.

- In both cultures, the microorganisms gradually modified the original galena surface, increasing the rest potential and the $\mathrm{SO}_{4}{ }^{2-}$ of the solid and liquid states.

- The particle size was apparently not a determining factor in the process.

- The galena was initially dissolved by acidic medium.

\section{Acknowledgement}

The authors would like to thank the biotechnology program of Colciencias, Colombia, the laboratory of biomineralogical of the National University of Colombia, Medellínd, Professor Diego Hernan Giraldo of the University of Antioquia, and the laboratory and group of molecular studies of the University of Antioquia.

\section{References}

Abraitis, P. K., Pattrick, R. A. D., Kelsall, G. H., Vaughan, D. J. 2004. Acid leaching and dissolution of major sulphide ore minerals: processes and galvanic effects in complex systems. Mineralogical Magazine. 68(2) 343-351 
Acero, P., Cama, J., Ayora, C. 2007. Rate law for galena dissolution in acidic environment. Chemical Geology. 245 219-229.

Al-Harahsheh, M., Kingman, S., Rutten, F., Briggs, D. 2006. ToF-SIMS and SEM study on the preferential oxidation of chalcopyrite. International Journal of Mineral Processing. $802-4$.

Bennett, J.C. and Tributsch, H. J. 1978. Bacterial leaching patterns on pyrite crystal surfaces. Bacteriol. 134:310-317.

Bolorunduro, S.A., Dreisinger, D.B., Van Weert, G. 2003. Zinc and silver recoveries from zinc-lead-iron complex sulphides by pressure oxidation. Minerals Engineering. 16 $375-389$.

Boon, M., Snijder, M., Hansford, G.S., Heijnen, J.J. 1998.The oxidation kinetics of zinc sulphide with Thiobacillus ferrooxidans. Hydrometallurgy. 48. 171 - 186.

Brierley J.A. \& Luinstra, L. 1993. Biooxidation-heap concept for pretreatment of refractory gold ore. In: Biohydrometallurgical Biohydrometallurgical Technologies, A.E.

Cardona I.C. 2008. Mineralogía del proceso de biodesulfurización de carbones provenientes de la zona río Aguachinte - río Asnazú (valle del cauca y cauca). Tesis de Maestría. Universidad Nacional de Colombia, sede Medellín.

Chernyshova., I.V. 2003. An in situ FTIR of galena and pyrite oxidation in aqueous solution. Vol 558. Pp. 83-98.

Cruz, R., Luna-Sánchez, R.M., Lapidus, G.T., González, I., Monroy, M. 2005. An experimental strategy to determine galvanic interactions affecting the reactivity of sulfide mineral concentrates. Hydrometallurgy 78 198- 208.

Da Silva, G. 2004a. Relative impoortance of diffusion and reaction control during the bacterial and ferric sulphate leaching of zinc sulphide. Hydrometallurgy. Vol. 73. pp. 313 - 324.

Da Silva, G. 2004b. Kinetics and mechanism of the bacterial and ferric sulphate oxidation of galena. Hydromatallurgy. $7599-110$.

Das T, Ayyappan S, Chaudhury G.R. 1999. Factors affecting bioleaching kinetics of sulfide ores using acidophilic micro-organisms. BioMetals, 12. 1-10.

Dutrizac, J.E., Chen, T.T. 1995. The leaching of galena in ferric sulfate media. Metallurgical and Materials Transactions. 26 219-227.

Fowler, T.A., Holmes, P.R., Crundwell, F.K. 1999. Mechanism of pyrite dissolution in the presence of Thiobacillus ferrooxidans. Applied Environmetanl Microbiology. 65 2987-2993.

Garcia, Jr, O., Bigham, J.M., Tuovinen, O.H. 1995. Oxidation of galena by Thiobacillus ferrooxidans and Thiobacillus thiooxidans. Canadian Journal Microbiology. 41. $508-514$.

Gerson, A., O'Dea, A. 2003. A quantum chemical investigation of the oxidation and dissolution mechanisms of Galena. Geochim. Cosmochim. Acta 67 (5) 813-822.

Jañczuk, B., Perea, R., González-Caballero., F. 1993.The influence of oxidation degree of galena surface and of ethyl xanthate on the stability of galena-air aggregates. Powder Technology. 75. $43-48$.

Lei Jiang, Huaiyang Zhou, Xiaotong Peng, Zhonghao Ding. 2008. Bio-oxidation of galena particles by Acidithiobacillus ferrooxidans. Particuology 6 99-105.

Liao, M.X., Deng, T.L. 2004. Zinc and lead extraction from complex raw sulfides by sequential bioleaching and acidic brine leach. Minerals Engineering. 1717 - 22. 
Marsden J. and House I. 1992. The chemistry of gold extraction. Ed. Ellis Horwood Limited, England.

Mizoguchi, T., Habashi, F. 1981. The aqueous oxidation of complex sulfide concentrates in hydrochloric acid. International Journal of Mineral Processing. 8 177-193.

Mousavi, S.M., Jafari, A., Yaghmaei, S., Vossoughi, M., Roostaazad, R. 2006. Bioleaching of low-grade sphalerite using a column reactor. Hydrometallurgy. 82 75-82

Muñoz, A., Márquez, M.A., Montoya, O.I., Ruiz, O., Lemehsko, V. 2003. Evaluación de oxidación bacteriana de sulfuros con Acidithiobacillus ferrooxidans mediante pruebas de FTIR y difracción de rayos X. REVISTA COLOMBIANA DE BIOTECNOLOGÍA. V. 73 - 81.

Muscat, J., Gale, J.D. 2003. First principles of the surface of galena PbS. Geochimica et Cosmochimica Acta. 67. (5) 799 - 805.

Naumann, D., Helm, D. 1995. FEMS Microbiology Letters. 12675

Nowak, P., Laajalehto, K., Kartio, I. 2000. A flotation related X-ray photoelectron spectroscopy study of the oxidation of galena surface. Colloids Surface. A 161. 447- 460 .

Olson, G. J., Brierley, J.A., Brierley, C.L. 2003. Bioleaching review part B: Progress in bioleaching: applications of microbial processes by the minerals industries. Appl Microbiol Biotechnol. 63 249-257.

Paar, W.H., Braithwaite, R.S.W., Chen, T.T., Keller, P. 1984. A new mineral, scotlandite (PbSO3) from Leadhills Scotland; the first naturally occurring sulphite. Mineralogical Magazine. 48283 - 288.

Patra, P., Natarajan, K.A. 2006. Surface chemical studies on selective separation of pyrite and galena in the presence of bacterial cells and metabolic products of Paenibacillus polymyxa. Journal of Colloid and interface Science. 298 (2) 720 - 729.

Peng, Y., Grano, S., Ralston, J., Fornasiero, D. 2002.Towards prediction of oxidation during grinding: I. Galena flotation. Minerals Engineering. 15493 - 498.

Rodriguez, Y., Ballester, A., Blázquez, M.L., Gonzalez, F., muñoz. J.A. 2003. New information on the sphalerite bioleaching mechanism at low and high temperature. Hydrometallurgy. $7157-66$.

Rohwerder, T.T., Kinzler, G.K. Sand, W. 2003. Bioleaching review part A: Progress in bioleaching: fundamentals and mechanisms of bacterial metal sulfide oxidation. Appl Microbiol Biotechnol. 63 239-248.

Santhiya, D., Subramanian, S., Natarajan, K.A. 2000. Surface chemical studies on galena and sphalerite in the presence of Thiobacillus thiooxidans with reference to mineral beneficiation. Minerals Engineering. 13(7) 747 - 763.

Sharma, P.K., Hanumantha, R. K. 2005. Miner. Metal. Process. 2231

Suzuki., I. 2001. Microbial laching of metals from sulfide minerals. Biotechnology Advances. 19. 119-132.

Urbano, G., Meléndez, A.M., Reyes, V.E., Veloz, M.A., Gonzáles, I. 2007. Galvanic interactions between galena - sphalerite and their reactivity. International Journal of Mineral Processing. 82148 - 155.

Waltling. H.R. 2006. The bioleaching of sulphide minerals with emphasis on copper sulphides - a review. Hydrometallurgy. 84 1-2 81-108.

Xia L., Liu J., Xiao L., Zeng J., Li B., Geng M. and Qiu G. 2008. Single and cooperative bioleaching of sphalerite by two kinds of bacteria-Acidithiobacillus ferriooxidans 
and Acidithiobacillus thiooxidans. Trans. Nonferrous Met. Soc. China. 12, pp 190195.

Zapata, D.M., Márquez M.A., Ossa, D.M. 2007. Sulphur product layer in sphalerite biooxidation: Evidences for a mechanism of formation. Advances Materials Research. 20-21 134 - 138. 


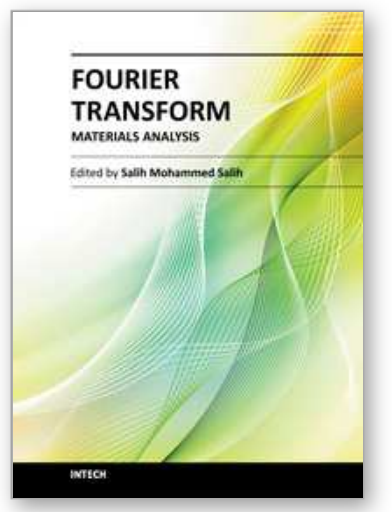

\author{
Fourier Transform - Materials Analysis \\ Edited by Dr Salih Salih
}

ISBN 978-953-51-0594-7

Hard cover, 260 pages

Publisher InTech

Published online 23, May, 2012

Published in print edition May, 2012

The field of material analysis has seen explosive growth during the past decades. Almost all the textbooks on materials analysis have a section devoted to the Fourier transform theory. For this reason, the book focuses on the material analysis based on Fourier transform theory. The book chapters are related to FTIR and the other methods used for analyzing different types of materials. It is hoped that this book will provide the background, reference and incentive to encourage further research and results in this area as well as provide tools for practical applications. It provides an applications-oriented approach to materials analysis written primarily for physicist, Chemists, Agriculturalists, Electrical Engineers, Mechanical Engineers, Signal Processing Engineers, and the Academic Researchers and for the Graduate Students who will also find it useful as a reference for their research activities.

\title{
How to reference
}

In order to correctly reference this scholarly work, feel free to copy and paste the following:

E. R. Mejia, J. D. Ospina, M. A. Marquez and A. L. Morales (2012). Bioleaching of Galena (PbS), Fourier Transform - Materials Analysis, Dr Salih Salih (Ed.), ISBN: 978-953-51-0594-7, InTech, Available from: http://www.intechopen.com/books/fourier-transform-materials-analysis/bioleaching-of-galena-pbs-

\section{INTECH}

open science | open minds

\section{InTech Europe}

University Campus STeP Ri

Slavka Krautzeka 83/A

51000 Rijeka, Croatia

Phone: +385 (51) 770447

Fax: +385 (51) 686166

www.intechopen.com

\section{InTech China}

Unit 405, Office Block, Hotel Equatorial Shanghai

No.65, Yan An Road (West), Shanghai, 200040, China

中国上海市延安西路65号上海国际贵都大饭店办公楼 405 单元

Phone: +86-21-62489820

Fax: +86-21-62489821 
(C) 2012 The Author(s). Licensee IntechOpen. This is an open access article distributed under the terms of the Creative Commons Attribution 3.0 License, which permits unrestricted use, distribution, and reproduction in any medium, provided the original work is properly cited. 